\title{
The role of basic blood parameters in determining the viability of intestinal tissue in incarcerated hernias
}

\author{
Rıfat Peksöz ${ }^{1}$, serkan karaisli² ${ }^{2}$ Kamil Erözkan ${ }^{3}$, and Enes A Ăırman ${ }^{4}$ \\ ${ }^{1}$ Affiliation not available \\ ${ }^{2}$ İzmir Kâtip Çelebi Üniversitesi \\ ${ }^{3}$ Muş state hospital \\ ${ }^{4}$ Atatürk Üniversitesi Tıp Fakültesi
}

April 30, 2021

\begin{abstract}
Objective: Abdominal hernia repair is a common surgery, with $15 \%$ of patients presenting as incarcerated hernias. In these cases, early diagnosis of intestinal ischemia and necrosis is crucial for mortality and morbidity. Biomarkers that can predict ischemia or necrosis status are vital. In this study, we aimed to reveal the roles of basic blood parameters in determining ischemia or necrosis status. Methods: The patients were divided into three groups as normal bowels (Group I: 24 patients), intestinal ischemia without necrosis (Group II: 31 patients), and Group III who underwent bowel resection because of necrosis (10 patients). Patients' demographic characteristics and blood parameters were retrospectively analyzed. Results: 65 patients operated for incarcerated abdominal hernias. There was no significant difference between the groups in terms of age, sex, comorbidity, or complications $(\mathrm{p}>0.05)$. The highest length of stay was observed in Group III $(\mathrm{p}<0.001)$. There were significant differences between the groups in terms of serum white blood cell (WBC), neutrophil, lymphocyte (LYM), neutrophil-lymphocyte ratio (NLR), urea, creatinine, total bilirubin, indirect bilirubin, lipase, C-reactive protein (CRP), and CRP/LYM levels ( $<<0.05$ ). Conclusion: Preoperative WBC, neutrophil, NLR, urea, creatinine, and total bilirubin levels can be used to predict the onset of intestinal ischemia. Serum creatinine, total bilirubin, indirect bilirubin, phosphorus, lactate dehydrogenase (LDH), and lipase levels can be used for bowel resection.
\end{abstract}

Title Page

The role of basic blood parameters in determining the viability of intestinal tissue in incarcerated hernias

Running head: The role of basic blood parameters in incarcerated hernias AUTHORS

Peksöz $R^{1}$, Karaisli $\mathrm{S}^{2}$, Erözkan $\mathrm{K}^{1}$, Ağırman $\mathrm{E}^{31}$ Department Of General Surgery, Muş State Hospital, Muş, Turkey.

${ }^{2}$ Department of General Surgery, İzmir Kâtip Çelebi University Atatürk Training and Research Hospital, İzmir-Turkey, ${ }^{3}$ Department Of General Surgery, Atatürk University Faculty of Medicine, Erzurum, Turkey.

Rifat Peksöz, Department of General Surgery, Muş State Hospital, Muş, Turkey, Orcid no: 0000-0003-46585254, E-mail:rifat-peksoz@hotmail.com

Serkan Karaıslı, Department of General Surgery, İzmir Kâtip Çelebi University Atatürk Training and Research Hospital, İzmir-Turkey, Orcid no: 0000-0001-8876-0191, E-mail: skaraisli@hotmail.com 
Kamil Erözkan, Department of General Surgery, Muş State Hospital, Muş, Turkey, Orcid no: 0000-00032193-9984, E-mail: kamilerozkan@gmail.com

Enes Ağırman, Department of General Surgery, Atatürk University Faculty of Medicine, Erzurum, Turkey, Orcid no: 0000-0002-0289-1252, E-mail: agirman_enes@hotmail.com

Correspondence Author: Rifat PEKSÖZ, Department of General Surgery, Muş State Hospital, Muş,Turkey, Postal Code:49100. E-mail: rifat-peksoz@hotmail.com Telephone: +905349214382

Funding: No funding.

Conflict of interest statement: The authors declare no conflict of interest.

\section{Hosted file}

Full_Text.pdf available at https://authorea.com/users/410036/articles/520222-the-roleof-basic-blood-parameters-in-determining-the-viability-of-intestinal-tissue-inincarcerated-hernias

\section{Hosted file}

Table's and Figures.pdf available at https://authorea.com/users/410036/articles/520222-therole-of-basic-blood-parameters-in-determining-the-viability-of-intestinal-tissue-inincarcerated-hernias 